\title{
Ribonuclease as a tumour marker for pancreatic carcinoma
}

\author{
G DORAN,* TG ALLEN-MERSH, $†$ AND KW REYNOLDS $\dagger$ \\ From the Departments of $\dagger$ Surgery and *Chemical Pathology, Charing Cross Hospital, \\ Fulham Palace Road, London W6 8RF, UK
}

SUMMARY Serum ribonuclease has been measured in 61 patients with a variety of inflammatory and malignant conditions. Serum activity is elevated in pancreatic carcinoma but it is not restricted to this condition. Levels were significantly elevated in cases of disturbed liver function.

Any enzyme that depolymerises RNA is a ribonuclease (RNAase). The work described here deals with those classes of RNAase which hydrolyse RNA into smaller oligonucleotide and mononucleotide units at pH optimum 6.5-6.7. Small amounts of an extracellular 'exocrine' form of this RNAase are secreted by the normal human pancreas into the gut. ${ }^{1}$ Reddi and Holland, ${ }^{2}$ who observed increased levels of serum RNAase in a series of patients with carcinoma of the pancreas, have suggested that this might represent increased enzyme synthesis by proliferating tumour cells within the pancreas. However, Peterson $^{3}$ has failed to confirm any specificity of elevated serum RNAase in the diagnosis of carcinoma of the pancreas.

We have assessed the potential of this assay to differentiate between carcinoma of the pancreas and other gastrointestinal conditions.

\section{Methods}

The method used was the same as that described by Reddi $^{4}$ with the exception that a precipitant mixture of perchloric acid and uranyl acetate was used instead of perchloric acid and lanthanum nitrate, which proved to be unreliable.

It is not possible to define the enzyme's activity in terms of international units because the molecular weight of the serum polynucleotide is unknown. A spectrophotometric unitage was adopted whereby the optical density (OD) at $250 \mathrm{~nm}$ was multiplied by 1000 ; hence an OD reading of test against blank of 0.001 implies 1 spectrophotometric unit of activity. The precision of the assay was quite good for this type of technique (coefficient of variation $7 \%$ ).

Received for publication 8 April 1980
NOR MAL VALUES

Serum RNAase level was estimated in 23 healthy adults (age range 20-40 years, 13 women). The upper limit of normal was defined as the normal mean (160 units) plus two standard deviations, ie, 264 units.

\section{Results}

Serum RNAase was assayed in 61 patients (Table). They were stratified into six main diagnostic groups; the distribution of activity in these groups is shown (Figure). The serum RNAase level was elevated in all cases of pancreatic carcinoma but elevated levels were not restricted to this condition. In patients with carcinoma of the colon (group C), the incidence and degree of elevation was of the same order as in patients with pancreatic carcinoma (group A). Levels were also elevated in a range of non-malignant

Diagnosis of patients studied in the survey, numbers investigated, and serum RNAase activity ranges/ individual values obtained

\begin{tabular}{|c|c|c|}
\hline Diagnosis & No. & $\begin{array}{l}\text { RNAase } \\
\text { (ranges/values) }\end{array}$ \\
\hline $\begin{array}{l}\text { Pancreatic carcinoma } \\
\text { Chronic pancreatitis } \\
\text { Carcinoma of colon } \\
\text { Carcinoma of oesophagus } \\
\text {," ", stomach } \\
\text { Crohn's disease } \\
\text { Diverticulitis } \\
\text { Colitis } \\
\text { Hiatus hernia } \\
\text { Duodenal ulcer } \\
\text { Cholecystitis } \\
\text { Chronic active hepatitis } \\
\text { Carcinoma of gallbladder } \\
\text { Hepatoma } \\
\text { Carcinoma of breast } \\
\text { Prostatic carcinoma } \\
\text { Prostatic hypertrophy }\end{array}$ & $\begin{array}{r}10 \\
4 \\
11 \\
3 \\
3 \\
3 \\
1 \\
2 \\
2 \\
1 \\
1 \\
2 \\
3 \\
1 \\
2 \\
1 \\
5 \\
3 \\
3\end{array}$ & $\begin{array}{l}300-1075 \\
140-524 \\
200-806 \\
217-509 \\
258-465 \\
128-272 \\
245 \\
283,396 \\
165,363 \\
564 \\
384 \\
217,451 \\
209-843 \\
578 \\
616,392 \\
334 \\
125-326 \\
164-215 \\
304-363\end{array}$ \\
\hline
\end{tabular}




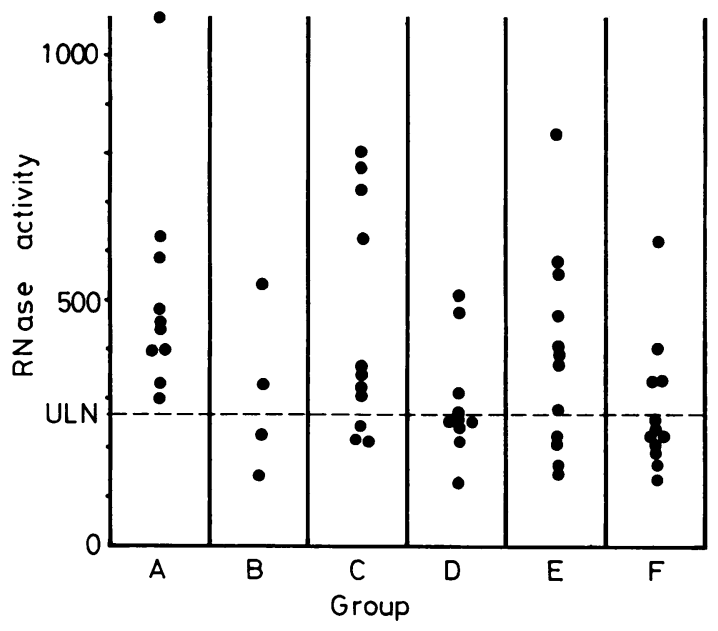

Scatter diagram of serum levels in relation to the upper limit of normal. Diagnostic groups: A-carcinoma of the pancreas; $B$ - pancreatitis; $C$-carcinoma of colon; $D$-other gut malignancies; E-hiatus hernia, ulcers, Crohn's disease, diverticulitis, colitis, cholecystitis, and hepatitis; F-tumours of gallbladder, liver, and breast.

conditions including pancreatitis and acute cholecystitis.

In one patient with a gastric carcinoma who underwent radical and apparently complete tumour resection, the level was not elevated preoperatively but rose during the first postoperative week and has remained elevated eight weeks after the operation. In two patients after total pancreatectomy for apparently complete tumour resection the serum level has remained elevated four weeks after operation in one case, and in the other it has returned to the normal serum level three months after operation.

\section{Discussion}

Elevation of the serum ribonuclease has not been found to be a specific marker for carcinoma of the pancreas. Considering the heterogeneity of molecular weight ${ }^{5}$ and origin ${ }^{6}$ of RNAase in serum, this is not surprising. The persistence of normal or elevated serum levels of RNAase after pancreatectomy, as reported earlier ${ }^{7}$ and confirmed by us, suggests that the pancreas contributes very little to serum levels.

The granulocytes produce an RNAase of the type that we have measured, and raised serum levels have been reported in myelogenous leukaemia. ${ }^{8}$ In our patients there was no correlation between enzyme activity and white cell count. It is also known that defective renal clearance of RNAase may result in elevated serum levels in myeloma, ${ }^{9}$ leukaemia, ${ }^{10}$ and renal failure. ${ }^{3}$ However, in none of our patients was the serum creatinine level elevated above the normal.

Serum RNAase levels were significantly elevated $(P<0.05)$ in those cases associated with disturbed liver function, that is, ascending cholangitis, hepatitis, primary and secondary hepatic malignancy without biliary obstruction, and biliary obstruction. The relationship noted between elevation of serum RNAase in acute pancreatitis and the development of pancreatic necrosis ${ }^{11}$ may be a reflection of this in those severe cases of pancreatitis associated with disturbed liver function. This serum RNAase may originate via exocytosis from hepatic parenchymal lysosomes. ${ }^{12}$

\section{References}

${ }^{1}$ Barnard EA. Ribonucleases. Ann Rev Biochem 1969;38: 677-732.

2 Reddi KK, Holland JF. Elevated serum ribonuclease in patients with pancreatic cancer. Proc Nat Acad Sci USA 1976;73:2308-10.

${ }^{3}$ Peterson LM. Serum RNAase in the diagnosis of pancreatic carcinoma. Proc Nat Acad Sci USA 1979;76: 2630-4.

${ }^{4}$ Reddi KK. Nature and possible origin of human serum ribonuclease. Biochem Biophys Res Commun 1975;67: 110-8.

- Schmukler M, Jewett PB, Levy CC. The effects of polyamines on a residue specific human plasma ribonuclease. J Biochem Chem 1975;250:2206-12.

${ }^{6}$ Neuwelt EA, Boguski MS, Frank JJ, Procter-Appich K, Levy CC. Possible sites of origin of human plasma ribonucleases as evidenced by isolation and partial characterisation of ribonucleases from several human tissue sources. Cancer Res 1978 ;38:88-93.

7 Houck JC, Berman LB. Serum ribonuclease activity. J Appl Physiol 1958;12:473-6.

${ }^{8}$ Akagi K, Yamanaka M, Murai K, Biho Y, Omae T. Serum acid ribonuclease in myelogenous leukaemia. Cancer Res 1978;38:2168-73.

${ }^{9}$ Karpetsky TP, Humphrey RL, Levy CC. Influence of renal insufficiency on levels of serum ribonuclease in patients with multiple myeloma. J Nat Cancer Inst 1977; 58:875-80.

${ }^{10}$ Humphrey RL, Karpetsky TP, Neuwelt EA, Levy CC. Levels of serum ribonuclease as an indicator of renal insufficiency in patients with leukaemia. Cancer Res 1977;37:2015-22.

${ }^{11}$ Warshaw AL, Lee KH. Serum ribonuclease elevations and pancreatic necrosis in acute pancreatitis. Surgery 1979; 86:227-34.

12 De Duve C, Pressman BC, Giannetto R, Wattiaux R, Appelmans $F$. Intracellular distribution of enzymes in rat liver tissue. Biochem $J$ 1955;60:604-17.

Requests for reprints to: Mr TG Allen-Mersh, University Department of Surgery, Charing Cross Medical School, Fulham Palace Road, London W6 8RF. 